\title{
THE IMPACT OF STRATEGY, INDUSTRY AND CULTURE ON FORECASTING THE PERFORMANCE OF \\ Global Competitors: A Strategic Perspective
}

\author{
Jeffrey P. Katz \\ Kansas State University \\ Manhattan, KS \\ Marilyn T. Zarzeski \\ University of Mississippi \\ University, MS \\ H. John Hall \\ University of Florida \\ Gainesville, FL
}

\begin{abstract}
This study examines how business strategy, industry competitive environment and national culture affect the accuracy and level of agreement among financial analysts who predict the future earnings of international competitors. Recent research has reported the increasing importance played by financial analysts regarding the stock price and market value of firms. Analysts' forecasts of performance have been found to significantly affect the cost of capital, valuation and stock price changes of firms. As the incidence of cross-national mergers and acquisitions continues to escalate, understanding factors that systematically affect performance predictions becomes increasingly important, especially for firms employing cross-national merger or acquisition strategies. We find that business strategies affect the accuracy of analysts' performance estimates while national culture plays an important role in determining the level of agreement among analysts' predictions. Implications and plans of action for international management practitioners and researchers are discussed.
\end{abstract}

\section{Background}

Strategic management seeks to integrate the traditional functionally-related business fields, such as economics, finance, marketing and accounting, by focusing on top management decisions having long-term impact on the future success of the firm (Andrews, 1987; Porter, 1985). The most commonly cited factor linking strategic management with these fields is the financial outcome of the firm. Describing how "strategic" factors focus on the external environment of the firm and affect the performance of the firm was the starting point for early models in strategic management (Hofer, 1975). For example, Porter's (1980) well-known 
model of competition serves as a basis for assessing the relative impact that key external factors, such as buyers, suppliers and rivals, have on competition within a particular industry. Thus, strategic management historically sought to address how contingent factors from the firm's external environment, and resulting decisions made within the firm, systematically affected financial performance of head-to-head competitors (Jauch, Osborn \& Glueck, 1980).

More recently, research in strategic management (Venkatraman \& Ramanujam, 1986), behavioral finance (Olsen, 1998) and financial accounting (Das, Levine \& Sivaramakrishnan, 1998; Shipper, 1991; and Dreman \& Berry, 1995) has attempted to expand our understanding of the factors affecting the prediction of future firm performance, with particular emphasis on the accuracy of indicators predicting future firm performance. This interest is increasing in importance as a strategic focus because understanding the factors affecting the accuracy of the firm's future earnings is key to understanding the firm's future valuation, cost of capital and the relationship between earnings and stock prices (Brown \& Rozeff, 1978). That is, factors affecting the accuracy of performance predictors have a direct impact on the strategic alternatives available to firm managers. Market valuation, stock price and cost of capital affect management's ability to implement broad competitive strategies, such as expanding the firm through mergers or acquisitions (Barton \& Gordon, 1988). Successful mergers and acquisitions are based on securing cost-effective capital through debt or equity markets (Abolafia, 1996; Shefrin \& Statman, 1993).

The potential implication for effective management of the firm is significant. By understanding factors affecting financial analysts' predictions of future firm performance, related changes in stock prices can be anticipated by managers and investors thus limiting the potentially negative impact of unexpected changes in firm valuation (Rivera, 1991). For example, Mann (1998) recently reported the single-day 24 percent market value decline of one company attributable to differences between financial analysts' estimates of the firm's earnings and the announcement by management of actual earnings. Despite the company's announcement that earnings would be equal to or slightly less than prior period earnings, financial analysts had incorrectly predicted substantial earnings increases.

Since capital markets value the information content of analysts' earnings estimates (Brown \& Rozeff, 1978), determining the factors that systematically affect analysts' earnings estimates is increasingly important to investors and creditors (Cheng, Chan \& Liao, 1997). In previous research, imputed accuracy of earnings estimates was found to significantly explain investors' beliefs about the future performance in the value of both a company and its stock price (Patell, 1976). Recent attention on the importance of performance estimates has resulted in the popular business press investigating the role of financial analysts and their estimation accuracy (Bartlett, 1998). Thus, the impact of firm performance estimates has become linked to the strategic decisions of top company managers. 
Extending firm performance estimation to the global marketplace, recent studies have begun examining factors contributing to the accuracy of performance estimates across global competitors. For example, Speidell and Ramos (1998) recently questioned whether international estimates of global competitor performance are useful in making strategic decisions. They suggest that performance projections by analysts may be less accurate for global competitors than for domestic firms, despite the assertion that approximately one-third of "quantitative" investors rely on performance estimates for international competitors. While noting that differences exist between performance forecasts for firms based in different countries, Spidell and Ramos offer no systematic explanation why such differences exist. In addition, several recent high-profile cross-national mergers, such as Chrysler and Daimler-Benz, have been the focus of analysts' earnings forecasts (Vlasic, Kerwin, Woodruff, Peterson \& Spiro, 1998).

In this study, we seek to gain a better understanding of the factors affecting performance predictions of global firms. Specifically, we investigate factors associated with "errors" in the estimates of earnings across global competitors relative to: 1.) the accuracy of financial analysts' estimates, and 2.) the causes of dispersion (systematic disagreement) among financial analysts' estimates, We develop and test a model predicting accuracy and agreement among analysts' estimates of future earnings that assesses the impact of factors stemming from three important information sources: 1 .) national cultures, 2.) industry competitive environments, and 3.) business strategies.

First, we examine estimated future firm performance based on the model tested by Katz, Zarzeski and Hall (1997) who examined the effect of business strategies, industry environments and national culture on actual firm performance. Second, we seek to extend Rivera's (1991) work by decomposing the industry competitive environment into specific task environments and assessing their impact on the accuracy and level of agreement of earnings predictions across global competitors. By considering the effects of national culture, industry factors and business strategies on analysts' predictions of firm performance, we find that business strategies are an important factor in determining the accuracy of analysts' earnings predictions while national culture plays an important role in the level of agreement among analysts' earnings predictions.

The next section presents the literature relating to forecast accuracy (analysts' forecast error) and level of agreement (forecast dispersion), national culture, industry environment and business strategy. The third section presents the methodology developed to operationalize and test the research hypotheses. Section four presents the results of our empirical tests while the final section discusses our results and offers action plans for international management practitioners and researchers. 


\section{Literature}

\section{Prediction of Performance}

Financial researchers and professionals agree that earnings are a major determinant of stock prices (Calderon, 1993; Conroy \& Harris, 1987). A significant portion of the research budget of investment bankers and brokerage houses is spent on compensating top financial analysts claiming the ability to accurately estimate the future earnings of firms. Professional analysis services, such as Institutional Broker's Estimate System (IBES), track financial analysts' earnings estimates for over 17,000 firms worldwide. Modern security analysis is the attempt by analysts to predict stock price movements by accurately estimating near-term firm performance (Dreman \& Berry, 1995).

Because earnings forecasts have information content of importance to the marketplace, the more accurate the earnings prediction, the more information content the forecast carries (Elton, Gruber \& Gultekin, 1981; 1984). Although the related literature since the late 1960's clearly suggests that analysts consistently mis-forecast earnings, there is little empirical evidence explaining the bases for the errors, especially across countries. For example, Brown, Richardson and Schwager (1987) examined the general concepts that underpin analysts' forecasts but did not examine the specific nature of firm, industry or decision settings (business strategies) that inherently impact financial analysts' decisions (Schipper, 1991).

Understanding the causes of errors in analysts' earnings forecasts is important to the corporate strategies available to the firm. Since the mid-1970's numerous authors have identified the multinational corporation (MNC) as a target for corporate strategy through portfolio diversification because MNC's, particularly those headquartered in foreign countries, are affected by different market risks than purely U.S. domestic firms (see for example, Solnik, 1974 and Fatemi, 1984). Domestic firms wishing to diversify their risk may seek to acquire firms in other countries but have relatively limited information about the future earnings of such firms. Therefore, the search for systematic "bias" in earnings predictions continues with limited investigation into prediction accuracy of MNCs (Rivera, 1991). Schipper (1991) suggested that examining the types (financial as well as strategic) of information available to analysts, and the context (environment) in which the firm being assessed competes, will potentially provide useful information about the accuracy of earnings estimates. Thus, by understanding the sources of estimation bias, managers are able to weigh the impact of such factors on the future earnings estimations and the likely financial market reaction.

The level of agreement, or dispersion, among analysts' estimates of earnings is an area of related interest. Forecast dispersion also carries important information to the marketplace (Elton et al, , 1981). If analysts have access to the same information, and interpret the information in the same manner, then their estimates of earnings will tend to be similar. However, if analysts with access to the same information make different interpretations, their level of disagreement (forecast 
dispersion) of estimates will be higher (Lang \& Lundholm, 1996). It has been suggested that higher levels of disagreement indicate higher levels of systematic risk (Conroy \& Harris, 1987; Elton et al., 1984). Thus, investigating the forces impacting analysts' forecast accuracy and dispersion will potentially provide important information to investors and managers about systematic differences in firm earnings and risk.

\section{The Industry Competitive Environment}

Early strategic management literature focused attention on industry factors affecting the firm's potential for sustaining market share and sales growth (Hofer, 1975). The firm's competitive environment, defined by the industry in which it chooses to compete, was initially characterized by the level of munificence - a concept meant to reflect the growth rates of specific industries over time. That is, an industry with a high level of munificence would be one in which firms are able to enter and maintain competitive positions with relative ease.

In 1979 Aldrich expanded the description of competitive environments by adding two more industry dimensions - complexity and dynamism. Environmental complexity describes the level of uniformity/heterogeneity of firms within an industry while environmental dynamism reflects the variability of industry growth, that is, relative market instability. The three industry dimensions form the context in which competitive strategies of the firm are developed and implemented (Hambrick \& Lei, 1985; Lee, Lee \& Ulgado, 1993).

In an effort to quantify and test the usefulness of the three conceptual industry factors, Dess and Beard (1984) developed and empirically tested industry competitive environments using standard industrial classifications (SIC) for measuring the three industry factors. Using the three measures of industry competition, Dess and Beard found systematic differences in the relationship between a firm's allocation of resources (business strategies) and its competitive environment. For 52 industries, Dess and Beard developed factor scores and ranks on munificence, complexity, and dynamism scales, thereby developing objective measures of the three dimensions comprising the firm's competitive environment. More recently, Rasheed and Prescott (1992) replicated and cross-validated the three industry dimensions reported by Dess and Beard (1984) finding considerable measurement stability for the three factors.

In the current study we employ munificence, dynamism and complexity measures to control for differences in industry competitive environments as a means to help us compare factors influencing analysts' estimations across different industries and competitive conditions. Thus, because industry effects across global competitors are difficult to predict, we control for the effects of different industry competitive environments (Prescott, 1986). The result is that all industries in our study are placed on a level playing-field relative to any special factors that might make certain industries easier, or more difficult, to track by financial analysts (Porter, 1990; Rivera, 1991). 


\section{The Role of Firm Strategy}

Within the constraints imposed by the industry's competitive environment, firms use their resources to develop strategies for competition in their marketplace which, in turn, affects the firm's financial performance (Andrews, 1987; Hambrick \& Lei, 1985; Porter, 1985). A strategy framework receiving considerable theoretical and empirical attention is the structure-strategy-performance model (Caves, Gale \& Porter, 1974; Porter, 1980; Scherer, 1970). This framework proposes that the performance of a company depends on the strategies undertaken within a particular industry's competitive structure. Managers able to effectively match the business strategies of the firm with the competitive environment will be rewarded by enhanced firm performance.

Extending the work of Porter (1980), McArthur and Nystrom (1991) examined the direct and moderating effects of the industry competitive on the strategyperformance relationship. They selected their sample of industries from Dess and Beard's (1984) study and found evidence that the competitive environment significantly interacts with strategies to affect performance. McArthur and Nystrom argued that the business environment modifies the form of the strategy-performance relationship. They recommended the use of all three industry competitive environment dimensions in future studies of strategy-performance.

More recently, Katz et al. (1997) sought to extend the work of McArthur and Nystrom (1991) by assessing the effects of strategy, industry and national culture on the actual financial performance of global competitors. They found financial performance is affected by the business strategies of the firm while holding industry and national culture constant across firms. Cheng, Etheridge and Noland (1994) and Franke, Hofstede and Bond (1991) have suggested that performance indicators of international firms possess a higher degree of informational complexity than domestic firms. Therefore, examining the role that business strategies play on the estimation of earnings will help increase the information content of performance predictions for global competitors and, hopefully, decrease the level of perceived risk associated with investments in international ventures (Shaked, 1986).

The current study seeks to examine business strategies in relation to financial analysts' predictions of firm performance. Because business strategies directly, or indirectly, affect firm performance (Hambrick, 1983; Hofer, 1975; Porter, 1985), we believe that firm strategies will be systematically related to financial analysts' earnings forecasts. Business strategies included in the current study are: 1.) inventory turnover, a measure of operational efficiency and a proxy for lowcost leadership; 2.) capital intensity, a measure of financial leverage; 3 .) financial slack, a measure of management's decision to maintain uncommitted financial resources for future market opportunities; 4.) research intensity, a measure of investment in research and development as a basis for future competitive advantage; and 5.) sales growth, a measure of industry market share (Katz et al., 1997; McArthur \& Nystrom, 1991). We chose these business strategies because they have been shown to reflect management's allocation of resources to the firm's 
competitive posture toward other firms in the same industry and the measures are accounting-based thus available world-wide to financial analysts tracking the performance of the firm.

\section{The Role of National Culture}

In the global marketplace the strategy-performance link has been shown to be affected by national culture, which stems from a country's values, norms and beliefs (Franke et al., 1991; Katz et al., 1997; Katz, Werner \& Brouthers, 1999). Twenty years ago, Hofstede (1980) conceptually and empirically defined culture as the collective mental programming of a nation's people. Hofstede developed a classification scheme for national cultures by identifying four bi-polar dimensions of national culture: individualism-collectivism, masculinity-femininity, high-low power distance and high-low uncertainty avoidance. Each of the four dimensions of national culture are scored on a continuous numeric scale, generally ranging from zero to 100 , allowing for the relative comparisons of worker attitudes between nations.

The first dimension, individualism, refers to the tendency of people to look after themselves and reflects the level of self-motivation and reward a culture encourages in its workforce. Nations having high levels of individualism will tend to encourage and reward workers for their individual efforts. At the other extreme is collectivism, the belief in the importance of group decision-making and group-oriented goals. For example, the United States is ranked high in individualism reflecting the value placed on individual achievement while Japan is ranked high in collectivism reflecting the group-oriented focus of workers in Japan.

The second dimension of national culture is masculinity, the degree of traditional masculine values, such as assertiveness and materiality, dominant in the nation. On the other-hand, femininity emphasizes concern for others and for the quality of work-life. Countries scoring high on the masculinity scale will encourage economic performance and rewards related to corporate growth while countries scoring high on the femininity scale will place greater emphasis on the quality of work-life. For example, Japan scores high on the masculinity scale reflecting a society valuing corporate growth while Denmark scores high on the femininity scale reflecting a society valuing a high quality of work life.

The third dimension of national culture is power distance, the level of acceptance by a society for the unequal distribution of power in organizations. High levels of power distance imply that workers expect to be given directions by a supervisor and expect highly bureaucratic organizational structures. On the other-hand, nations scoring low on the power distance scale will have workers approaching the workplace in a more egalitarian manner expecting flatter organizational structures and seeking worker input from the lowest levels of the organization. For example, countries such as France score relatively high, while the United States scores relatively low, on the power distance scale. 
Finally, uncertainty avoidance is the extent to which people feel threatened by ambiguity in the workplace. High levels of uncertainty avoidance suggest workers in a nation will not easily make decisions on their own but will instead seek written procedures. Conversely, nations scoring low on the uncertainty scale will have workers willing to make decision under risky conditions. For example, Germany scores relatively high on the uncertainty avoidance scale reflecting workers who are more comfortable with rules and written procedures while the United States scores relatively low on the uncertainty avoidance scale reflecting workers more likely to make decisions under conditions with greater uncertainty.

Hofstede (1983) and Franke et al. (1991) suggest that national culture influences the development and implementation of strategies used to accomplish the firm's competition goals. In this context, Hofstede's theory of national culture predicts that culture will significantly affect business strategies as vehicles to achieve organizational success. Recent research supports this contention. For example, Katz et al. (1999) empirically tested a model predicting the importance of culture on business goals. They demonstrated that national culture, particularly individualism/collectivism, affects growth strategies and performance of firms in the international banking industry. Thus, since national culture affects the strategies and performance of the firm (Osland \& Cavusgil, 1996), it is likely that national culture will affect the ability to predict the future performance of the firm.

Numerous studies have shown that financial reporting practices of firms differ across cultures (Choi, 1973; Barrett, 1976; Adhikari \& Tondkar, 1992). Prior research indicates that firms develop practices to solve problems arising from their deriving value from business transactions (Rockart, 1979). Financial reporting results from practical solutions developed at the firm (micro) level and institutionalized through disclosure practices at the industry and national (macro) levels (Leblebici \& Salancik, 1982). Zarzeski (1996) found that national cultural impacts the level of financial reporting in firms across seven developed countries. She implied there is reason to believe that a greater level of financial reporting, and related company information, will be positively associated with the number of financial analysts tracking and estimating the future performance of a company. In summary, there is evidence to suggest that national culture, industry competitive factors and business strategies will affect how financial analysts interpret the future performance of global competitors. However, no study has examined the relationship between national culture, company strategy and the accuracy or, or agreement between, financial analysts' estimates of future firm performance in a single predictive model. Therefore, the current study seeks to examine whether national culture affects analysts' earnings forecasts by assuming cultural differences are related to financial reporting differences as well as business, political, and economic differences across countries (Das \& Saudagaran, 1998; Das et al., 1998). 
Figure 1

\section{Conceptual Factors Affecting the Financial Performance Forecasting}

\begin{tabular}{llllll}
\hline $\begin{array}{l}\text { National } \\
\text { Factors } \rightarrow\end{array}$ & $\begin{array}{l}\text { Cultural } \\
\text { Factors } \rightarrow\end{array}$ & $\begin{array}{l}\text { Industry } \\
\text { Factors } \rightarrow\end{array}$ & $\begin{array}{l}\text { Strategy } \\
\text { Factors } \rightarrow\end{array}$ & $\begin{array}{l}\text { Past } \\
\text { Perf. } \rightarrow\end{array}$ & $\begin{array}{l}\text { Performance } \\
\text { Estimation }\end{array}$ \\
\hline $\begin{array}{l}\text { Economic } \\
\text { systems }\end{array}$ & Values & $\begin{array}{l}\text { Growth } \\
\text { rate }\end{array}$ & Efficiency & $\begin{array}{l}\text { Profit } \\
\text { stability }\end{array}$ & Accuracy \\
\hline $\begin{array}{l}\text { Legal } \\
\text { systems }\end{array}$ & Norms & $\begin{array}{l}\text { Firm } \\
\text { homogeneity }\end{array}$ & Effectiveness & $\begin{array}{l}\text { Depth of } \\
\text { knowledge }\end{array}$ & $\begin{array}{l}\text { Variability } \\
\text { (level of } \\
\text { agreement) }\end{array}$ \\
\hline $\begin{array}{l}\text { Political } \\
\text { systems }\end{array}$ & Beliefs & Market & & & \\
\hline
\end{tabular}

Technology

Adapted from: Katz et al., 1997

Figure 1 depicts the proposed relationships between national level (culture), industry level (competitive environment) and firm level (strategies) factors potentially affecting analysts' forecasting of company performance (accuracy and dispersion). It is in this context that global competitors attempt to use the resources at their disposal to develop sustainable competitive advantage and in which financial analysts predict the results of business strategies on the performance of the firm. Therefore, based on the previous discussion, we propose the following research hypotheses:

Hypothesis 1: Holding differences in national culture and industry competitive environment constant, firm strategies will significantly affect the accuracy of financial analysts' estimates of future firm earnings.

Hypothesis 2: Holding differences in industry competitive environment and firm strategies constant, national culture will significantly affect the dispersion of financial analysts' estimates of future firm earnings.

\section{Methodology}

In order to test our hypotheses, we identified previously validated measures of national culture, industry and strategy. We proposed two regression models related to financial analysts' earnings forecasting behavior: forecast error and forecast dispersion. In the Earnings Forecast Error Model, we tested the effects that firm 
strategies have on analysts' ability to predict future firm performance, while controlling for national culture and industry factors. In the Earnings Forecast Dispersion Model, we tested the effects of national culture on analysts' ability of predict future firm performance, while controlling for business strategy and industry competitive conditions.

Data was collected from four sources. Financial data used to assess actual firm performance and business strategies was collected from Standard and Poor's Global Vantage data base for five years covering 1988-1992. We controlled for the diversity of industry competitive environments by collecting data on companies doing business in 30 specific industries at the four digit SIC level identified by Dess and Beard (1984) as being in the highest and lowest ranges of the three industry environmental dimensions. We collected data on the four dimensions of national culture for each global competitor by using the numeric scores for more than 20 home countries as published in Hofstede (1980). Finally, I/B/E/S International provided earnings forecast and dispersion data for each firm. Our goal was to develop and test two models replicating the information generally available to financial analysts for their prediction of future company performance.

We chose the 1988-1992 period for collection of historical financial performance information for three reasons. First, we were interested in assessing the accuracy and dispersion of analysts' estimating behavior during a period of relative economic stability to ensure the most consistent results possible. Since the historical financial data was after the 1986 U.S. tax act that radically changed the treatment of investment depreciation, we felt the impact of the change in the U.S. tax code would take a year or so to be fully understood by financial analysts. Second, the data for 1988-1992 was prior to the effective dates of changes in accounting standards that modified the handling of deferred income taxes which we believed would make international comparisons difficult. Finally, the data collected was prior to the increased merger/IPO activity that began around 1994. Thus, we felt comparing analysts' estimates of future company performance versus the companies' actual performance, along with financial data from 1988-1992, was conducted during one of the most stable reporting periods for international firms over the last 15 years.

The measures employed are summarized in Figure 2 comparing the concepts discussed in the literature review to the operational measures. For both models, the control factors consist of the three measures of the industry competitive environment - munificence, complexity and dynamism. The Earnings Forecast Error Model's independent variables of primary interest are five measures of firm strategies (inventory turnover, capital intensity, financial slack, research intensity and sales growth). The Earnings Forecast Dispersion Model's independent variables of primary interest are the four dimensions of national cultural individuality/collectivism, power distance, ambiguity avoidance and masculinity/ femininity. 
Figure 2

Operationalized Factors Affecting the Financial Performance Forecasting

\begin{tabular}{lllll}
\hline $\begin{array}{l}\text { National } \\
\text { Culture } \rightarrow\end{array}$ & $\begin{array}{l}\text { Task } \\
\text { Environment } \rightarrow\end{array}$ & $\begin{array}{l}\text { Firm } \\
\text { Strategies } \rightarrow\end{array}$ & $\begin{array}{l}\text { Past Financial } \\
\text { Performance } \rightarrow\end{array}$ & $\begin{array}{l}\text { Expected Future } \\
\text { Performance }\end{array}$ \\
\hline Individuality & Munificence & $\begin{array}{l}\text { Inventory } \\
\text { turnover }\end{array}$ & $\begin{array}{l}\text { Earnings } \\
\text { stability }\end{array}$ & Estimation error \\
\hline Masculinity & Complexty & Capital intensity & \\
\hline Power Distance & Dynamism & Financial slack & $\begin{array}{l}\text { Number of } \\
\text { estimates }\end{array}$ & $\begin{array}{l}\text { Agreement among } \\
\text { estimates } \\
\text { (dispersion) }\end{array}$ \\
\hline Uncertainty & Research & \\
Avoidance & intensity & \\
\hline
\end{tabular}

Adapted from: Katz et al., 1997

\section{Control Factors}

Task Environment. To control for competitive differences in industries, data was collected for all firms in 30 industries nested into the five highest and five lowest ranked industries on the munificence, dynamism, and complexity factors developed by Dess and Beard (1984). To find the relative five highest and five lowest industries, the standardized factor scores in the Dess and Beard study were rank ordered. Our total sample contained 421 firms representing 30 industries (five industries for each of the three high and low conditions). A validation of the Dess and Beard (1984) study was conducted by Rasheed and Prescott (1992), providing assurance regarding the accuracy of the rankings used in the present study. For example, in the environmental dimension, "complexity," which is used to define the relative level of protection an industry has due to the complex nature of the processes employed, data for all firms in the "high" condition in SIC 2820, plastics and synthetic rubber manufacturing was collected, while data for firms in the "low" condition were chosen from SIC 2080, beverage bottling. Considering the relative differences in complexity of manufacturing processes between plastics and beverage bottling, particularly the impact of patents, it is highly likely that competition in the two industries would be significantly different. Table 1 displays examples of the industry dimensions, sample SICs and definitions of firms in each the six control groups. 
Table 1

Measures and Examples of Industry Environment Dimensions

\begin{tabular}{llll}
\hline $\begin{array}{l}\text { Environment } \\
\text { Dimension }\end{array}$ & $\begin{array}{l}\text { Industry } \\
\text { Condition }\end{array}$ & $\begin{array}{l}\text { Example } \\
\text { Industry SIC }\end{array}$ & Company Descriptions \\
\hline Munificence & High & 3570 & Computer and office equipment \\
& Low & 3670 & Computer circuits and chips \\
\hline Dynamism & High & 3330 & Metal smelting and refining \\
& Low & 3640 & Electric bulb and lamp manufacturing \\
\hline Complexity & High & 2820 & Plastics and synthetic rubber manufacturing \\
& Low & 2080 & Beverage bottling \\
\hline
\end{tabular}

Size and Variability. Two additional variables are included in the model to control for company size: the natural $\log$ of total firm assets and the total number of estimates for each firm. Typically, large companies provide more information to investors and are followed by more analysts because of the amount of information provided to make predictions (Shipper, 1991). A third variable, earnings stability, is included to control for the variability of earnings of each firm as suggested by Das et al., (1998). The five-year earnings variation calculated by $\mathrm{I} / \mathrm{B} / \mathrm{E} / \mathrm{S}$ is the measure used for firm earnings stability.

\section{Strategy Measures}

Five measures of business strategies were used as predictors of firm performance. Since we are interested in assessing the impact of resource use (strategies) on performance prediction, three business strategies used by McArthur and Nystrom (1991) for which international data was available were replicated: inventory turnover, capital intensity, and financial slack. In addition, research intensity and sales growth were also employed to capture technology and market dominance as potentially related to earnings predictions (Hambrick, 1983; Shane, 1993). While these measures do not generally constitute a complete set of organizational strategies, they tend to provide a good sample of the strategies employed by firms in order to compete within industries and are based on information available to financial analysts through financial statements (Hitt \& Ireland, 1987).

In order to eliminate effects related to firm size, financial ratios were used for all firm-level predictors. Specifically, inventory turnover is the ratio of sales to inventory; capital intensity is the ratio of assets to sales; financial slack is stockholders' equity as a percentage of total debt; research intensity is the ratio of sales to research and development expenses; and sales growth is the annual change in gross sales. All ratios were averaged over the five-year period to eliminate any potential effects attributed to cyclical variations due to macro-economic factors such as exchange rates or national recessions. 


\title{
Cultural Measures
}

In order to assess the impact of national culture on business strategies and earnings forecasts, scores for the four dimensions of national culture (individuality, power distance, uncertainty avoidance and masculinity) as reported in Hofstede (1980) were used. Scores for the four cultural dimensions for each country are on a continuous scale ranging from 6 to 112. For example, the individualism score for the United States is 91 while the individualism score for Japan is 46 . The uncertainty avoidance score for the United States is 46 while the uncertainty avoidance score for Mexico is 82 . Thus, firms headquartered in the United States, relative to those headquartered in Japan, would be considered to have higher levels of individualism guiding the decisions of managers concerning business strategies of the firm.

\section{Dependent Variables}

We measured the dependent variables of the two forecast models as follows:

\author{
Earnings Forecast Error $=$ \\ In (Actual Mean EPS - Forecast Mean EPS)/Actual Mean EPS.
}

Earnings Forecast Dispersion $=$ ln (Standard Deviation of EPS Forecast).

A logarithmic transformation of each measure was employed to ensure a normal distribution.

\section{Results}

Table 2 reports the means, standard deviations and bivariate correlations for the measures employed. The negative average forecast error $(-2.23)$ reflects the systematic underestimation of earnings by financial analysts and is consistent with results reported in prior research (see for example, Lang \& Lundholm, 1996).

On a bivariate basis, forecast error was found to be significantly correlated with the level of industry dynamism, national culture measured by individualism and business strategies measured by inventory turnover, capital intensity, financial slack and research intensity. Specifically, the incidence of forecast error was positively associated $(\mathrm{r}=.11, \mathrm{p}<.05)$ with industries having a high level of dynamism and a negative association $(r=-.09, p<.10)$ with industries having a low level of dynamism. This makes sense since it would be more difficult for financial analysts to accurately forecast earnings in a dynamically changing industry compared to an industry that is relatively stable. As expected, the relationships between forecast accuracy and firm size, earnings stability and number of estimates were found to be negative indicating that more information about the company results in more accurate estimations of future performance. 
Table 2

Means, Standard Deviations and Correlations

\begin{tabular}{|c|c|c|c|c|c|c|c|c|c|c|c|c|}
\hline & Mean & St D & 1 & 2 & 3 & 4 & 5 & 6 & 7 & 8 & 9 & 10 \\
\hline 1 Forecast Error & -2.23 & 1.58 & 1.00 & & & & & & & & & \\
\hline 2 Forecast Dispersion & -1.23 & 2.57 & $.22^{* * *}$ & 1.00 & & & & & & & & \\
\hline 3 Munificence High & 0.31 & 0.46 & .01 & $-.16^{* * *}$ & 1.00 & & & & & & & \\
\hline 4 Munificence Low & 0.22 & 0.41 & .01 & -.00 & $-.35^{* * *}$ & 1.00 & & & & & & \\
\hline 5 Dynamism High & 0.13 & 0.34 & $.11^{* *}$ & .03 & $-.26 * * *$ & $-.20^{* * *}$ & 1.00 & & & & & \\
\hline 6 Dynamism Low & 0.10 & 0.31 & $-.09^{*}$ & $-.09 *$ & $-.23 * * *$ & $-.18 * * *$ & $-.13^{* * *}$ & 1.00 & & & & \\
\hline 7 Complexity High & 0.15 & 0.36 & .02 & $.15^{* * *}$ & $-.28 * * *$ & $-.22 * * *$ & $-.16 * * *$ & $-.14^{* * *}$ & 1.00 & & & \\
\hline 8 Complexity Low & 0.09 & 0.29 & $-.09 *$ & $.11^{* *}$ & $-.21 * * *$ & $-.17^{* * *}$ & $-.13 * * *$ & $-.11 * *$ & $-.13 * * *$ & 1.00 & & \\
\hline 9 Uncertainty Avoidance & 58.25 & 23.50 & .07 & $.61^{* * *}$ & $-.17 * * *$ & .01 & -.04 & -.03 & $.14^{* * *}$ & $.16^{* * *}$ & 1.00 & \\
\hline 10 Power Distance & 44.54 & 12.27 & -.03 & $.17^{* * *}$ & .05 & .00 & $-.12 * *$ & -.04 & .06 & .06 & $.37 * * *$ & 1.00 \\
\hline 11 Masculinity & 65.38 & 20.46 & .02 & $.18^{* * *}$ & -.07 & .02 & -.08 & .00 & .03 & .03 & $.66^{* * *}$ & $.27 * * *$ \\
\hline 12 Individualism & 71.18 & 22.46 & $-.10^{*}$ & $-.48 * * *$ & .08 & .05 & .06 & .05 & $-.15 * * *$ & $-.15^{* * *}$ & $-.45^{* * *}$ & $-.65 * * *$ \\
\hline 13 Company Size & 11.34 & 1.97 & $-.20 * * *$ & $-.52 * * *$ & $.17^{* * *}$ & .02 & -.07 & .00 & $-.09^{*}$ & $-.11^{*}$ & $-.35 * * *$ & $-.19 * * *$ \\
\hline 14 Earnings Stability & 34.82 & 32.42 & $-.27 * * *$ & -.01 & -.01 & .03 & $.16^{* * *}$ & $-.16^{* * *}$ & -.02 & -.06 & -.04 & -.06 \\
\hline 15 Number of Estimates & 9.35 & 7.95 & $-.17 * * *$ & $-.18 * * *$ & $.12^{* *}$ & .00 & .05 & $-.12^{* * *}$ & -.03 & -.08 & $-.20 * * *$ & .06 \\
\hline 16 Inventory Tumover & 7.92 & 7.95 & $-.13 * *$ & $14^{* * *}$ & $.09^{*}$ & -.08 & -.07 & -.02 & .00 & $.09 *$ & .05 & .05 \\
\hline 17 Capital Intensity & .47 & .39 & $.09^{*}$ & .07 & $-.17 * * *$ & -.06 & $.23 * * *$ & -.06 & .01 & $.13^{* *}$ & -.06 & .02 \\
\hline 18 Financial Slack & .46 & .20 & $-.18 * * *$ & $-.33 * * *$ & $.12^{* *}$ & .09 & $-.10^{* *}$ & .01 & -.09 & $-.10^{* *}$ & $-.29 * * *$ & -.02 \\
\hline 19 Research Intensity & .07 & .17 & $.17^{* *}$ & $-.13^{*}$ & $.19 * *$ & .00 & -.10 & -.08 & -.10 & -.05 & -.06 & -.05 \\
\hline 20 Sales Growth & 15.12 & 26.76 & .03 & $-.09^{*}$ & $.15^{* * *}$ & .01 & $-.10^{*}$ & -.06 & -.02 & -.04 & -.05 & .07 \\
\hline
\end{tabular}

two-tailed test $\mathrm{p}$-values: ${ }^{*} \mathrm{p} \leq .10,{ }^{* *} \mathrm{p} \leq .05,{ }^{* *} \mathrm{p} \leq .01$ 
Table 2 Continued

Means, Standard Deviations and Correlations

\begin{tabular}{|c|c|c|c|c|c|c|c|c|c|c|c|c|}
\hline & Mean & St D & 1 & 2 & 3 & 4 & 5 & 6 & 7 & 8 & 9 & 10 \\
\hline 1 Forecast Error & -2.23 & 1.58 & & & & & & & & & & \\
\hline 2 Forecast Dispersion & -1.23 & 2.57 & & & & & & & & & & \\
\hline 3 Munificence High & 0.31 & 0.46 & & & & & & & & & & \\
\hline 4 Munificence Low & 0.22 & 0.41 & & & & & & & & & & \\
\hline 5 Dynamism High & 0.13 & 0.34 & & & & & & & & & & \\
\hline 6 Dynamism Low & 0.10 & 0.31 & & & & & & & & & & \\
\hline 7 Complexity High & 0.15 & 0.36 & & & & & & & & & & \\
\hline 8 Complexity Low & 0.09 & 0.29 & & & & & & & & & & \\
\hline 9 Uncertainty Avoidance & 57.65 & 23.50 & & & & & & & & & & \\
\hline 10 Power Distance & 44.56 & 12.27 & & & & & & & & & & \\
\hline 11 Masculinity & 65.07 & 20.46 & 1.00 & & & & & & & & & \\
\hline 12 Individualism & 70.93 & 22.46 & $-.31 * * *$ & 1.00 & & & & & & & & \\
\hline 13 Company Size & 11.34 & 1.97 & -.03 & $.59 * * *$ & 1.00 & & & & & & & \\
\hline 14 Eamings Stability & 7.92 & 7.95 & -.05 & .09 & -.06 & 1.00 & & & & & & \\
\hline 15 Number of Estimates & 9.35 & 0.90 & $-.17 * * *$ & $.13^{* * *}$ & $.42^{* * *}$ & $-.12 * *$ & 1.00 & & & & & \\
\hline 16 Inventory Turnover & 7.92 & 7.95 & .05 & $-.11 * *$ & -.03 & -.09 & .05 & 1.00 & & & & \\
\hline 17 Capital Intensity & .47 & .39 & -.08 & $-.12^{* *}$ & $-.10^{* *}$ & .02 & -.04 & -.01 & 1.00 & & & \\
\hline 18 Financial Slack & .46 & .20 & -.08 & $.18 * * *$ & .03 & $-.12^{*}$ & -.01 & .08 & -.01 & 1.00 & & \\
\hline 19 Research Intensity & .07 & .17 & -.02 & .09 & -.07 & .02 & -.08 & .00 & .08 & $.13^{*}$ & 1.00 & \\
\hline 20 Sales Growth & 15,12 & 26.76 & -.02 & -.01 & .00 & -.07 & .07 & -.01 & -.01 & $.13^{* *}$ & $.82^{* * *}$ & 1.00 \\
\hline
\end{tabular}

two-tailed test $\mathrm{p}$-values: ${ }^{*} \mathrm{p} \leq .10,{ }^{* *} \mathrm{p} \leq .05,{ }^{* * *} \mathrm{p} \leq .01$ 
In regard to forecast dispersion, significant bivariate relationships are evident in industry competitive environments which have higher levels of munificence $(r=.16, p<.01)$, higher levels of complexity $(r=.15, p<.01)$ and lower levels of complexity $(r=.11, p<.05)$. Analysts' forecasts of earnings were found to be marginally less dispersed in industries with lower levels of dynamism $(r=-.09$, $p<.10$ ). Forecast dispersion was found to be significantly associated $(p<.01)$ with all four measures of national cultural consistent with Franke et al. (1991). In addition, the size of the company and the number of analysts following the company resulted in lower variance among the analysts' estimates of earnings as predicted.

Table 3 reports the results of the Earnings Forecast Error Model. The results generally support Hypothesis 1. That is, controlling for the effects of industry factors, the level of forecast error is significantly related to management decisions to allocate resources that result in changes to the rate of inventory turnover (a measure of relative operational efficiency), financial slack (a measure of management's decision to use cash as a competitive weapon), and research intensity (management's decision to use investment in research and development as a basis for firm growth). These results are consistent with Mitroff and Mohrman (1987) and Nakata and Sivakumar (1996). The results of the model also indicate that national culture, specifically individuality $(b=-.15, p=.02)$, results in lower forecast error. Overall, the results of the Earnings Forecast Error Model make sense. Prior research has indicated that business strategies are significant determinants of firm performance, controlling for industry and national cultural factors (Katz et al., 1997). Overall, the model explains 12 percent $(\mathrm{p}<.0001)$ of the variance in earnings forecast errors made by financial analysts.

Table 4 reports the results of the Earnings Forecast Dispersion Model. The results support Hypothesis 2 . That is, controlling for industry competitive factors and business strategies, national culture has a significant impact on the level of agreement among financial analysts with regard to future earnings of the firm. Interestingly, all of the measures of culture are negatively associated with forecast dispersion (lower dispersion) except uncertainty avoidance $(b=.75, p=.001$ ). Perhaps this occurs because in countries having lower levels of uncertainty avoidance, such as the United States, it is more difficult for analysts to agree on the future earnings of the firm (Gray, Shaw \& McSweeney, 1981; Peterson et al., 1995). Conversely, in cultures where workers actively avoid uncertainty, such as Japan, financial analysts are less able to gain consensus on earnings forecasts because workers are unwilling to disclose operational vagaries resulting from the firm's competitive environment or strategies employed by the firm.

In the Earnings Forecast Dispersion Model, the only significant business strategy found to affect the level of forecast dispersion is inventory turnover ( $b=.09$, $p=.008)$. Neither the size of the firm nor the variability of earnings appears to significantly impact estimate dispersion. Overall, the model explains 54 percent $(\mathrm{p}<.0001)$ of the variation in financial analysts' earnings forecast dispersion. 
Table 3

Earnings Forecast Error Model: Regression of Strategy, Environment, and National Culture on Forecast Error

\begin{tabular}{lcccc}
\hline \multicolumn{1}{c}{ Variables } & B & SE Beta & \multicolumn{1}{c}{ Beta } & P-Value \\
\hline Inventory Turnover & .03 & .009 & $\mathbf{. 1 3 7}$ & .003 \\
Capital Intensity & .30 & .194 & .076 & .119 \\
Financial Slack & -1.05 & .377 & $\mathbf{- 1 4 1}$ & .005 \\
Research Intensity & 2.04 & .830 &. $\mathbf{1 5 8}$ & .014 \\
Sales Growth & -.003 & .004 & -.055 & .392 \\
Earnings Stability & .01 & .003 & $\mathbf{- 1 4 9}$ & .002 \\
Number of Estimates & -.03 & .009 & $\mathbf{- . 1 3 2}$ & .008 \\
Uncertainty & .001 & .004 & .022 & .751 \\
Power Distance & -.01 & .008 & -.018 & .091 \\
Masculinity & .03 & .005 & -.007 & .917 \\
Individuality & -.01 & .004 & -.151 & .023 \\
Constant & -.45 & .677 & & \\
Adjusted R & .12 & & & \\
F & 4.55 & & & \\
P-Value & .0001 & & & \\
\hline
\end{tabular}

Table 4

Earnings Forecast Dispersion Model: Regression of Strategy, Environment, and National Culture on Forecast Dispersion

\begin{tabular}{lcccc}
\hline \multicolumn{1}{c}{ Variables } & B & SE Beta & Beta & P-Value \\
\hline Inventory Turnover & .03 & .011 &. $\mathbf{0 9 0}$ & .008 \\
Capital Intensity & .27 & .232 & .040 & .251 \\
Financial Slack & -.67 & .449 & -.054 & .135 \\
Research Intensity & 1.14 & .988 & .053 & .251 \\
Sales Growth & -.003 & .004 & -.036 & .445 \\
Earnings Stability & .001 & .003 & .014 & .682 \\
Number of Estimates & -.002 & .001 & -.005 & .882 \\
Uncertainty & .08 & .005 &. $\mathbf{7 5 4}$ & .001 \\
Power Distance & -.06 & .009 & $\mathbf{- . 2 8 0}$ & .001 \\
Masculinity & -.05 & .005 & $\mathbf{. 3 7 6}$ & .001 \\
Individuality & -.04 & .005 & $\mathbf{- . 3 9 8}$ & .001 \\
Constant & 2.65 & .807 & & \\
Adjusted R & .54 & & & \\
F & 32.30 & & & \\
P-Value & .0001 & & & \\
\hline
\end{tabular}




\section{Discussion}

We began this study by seeking to better understand the relationship between business strategies and analysts' earnings forecasts of global competitors while taking into account culture and industry factors previously suggested to affect the structure-strategy-performance relationship. Prior research has documented the importance of psychological processes used by financial analysts in making market predictions. Specifically, Hunter and Coggin (1988) reported that human judgement is more important in determining the accuracy of earnings forecasts than the efficient market hypothesis which assumes all available information is viewed uniformly by financial analysts. We believe that our results extend the work of Hunter and Coggin (1988) by examining the broad array of information used by financial analysts in a more fine-grained cross-sectional model than previous approaches.

By hypothesizing that business strategies would influence earnings forecasts, we sought to control for the effects of national culture and industry on the estimation of future performance by financial analysts - experts employed to predict future success, or failure, of international competitors. Our study provides evidence that business strategies are a major influence on the accuracy of financial analysts' earnings forecasts of international competitors. Our study also provides evidence that national culture is a dominant influence affecting the level of agreement among financial analysts' with regard to future earnings forecasts. It is, therefore, not surprising that previous exploratory research has shown understanding the factors affecting consensus earnings estimates in world financial markets is important in assisting firms in their diversification strategies (Erickson \& Cunniff, 1995). Thus, by examining the effects of four dimensions of national culture, we extended the existing research beyond the domestic/multinational dichotomy typically employed in recent research (Cheng, Chan \& Liao, 1997), and sought to assess the relative impact of specific cultural factors on the level of agreement among financial analysts. We believe these findings have significant implications for global managers, investors/financial analysts and academic researchers.

\section{Implications for Global Managers}

Our results provide evidence that global managers employing fast-paced strategies such as high levels of research and development investment, indicative of a differentiation strategy, and high levels of inventory turnover, indicative of a low-cost leadership strategy, may be providing an environment of prediction uncertainty for financial analysts. Therefore, managers choosing these strategies should provide management earnings estimates and other data for use by financial analysts in order to lessen the financial market impact resulting from a more complex set of strategies. For example, Gonsalves and Eiler (1996) suggest it is important for managers to understand the impact of complexity on the operations of the firm and report in ways that will help stockholders and investors understand 
complexity faced by the firm. It is clear that stable earnings help financial analysts to more accurately predict future earnings.

Across countries, there is evidence that firms in countries having higher levels of power distance systematically have lower analysts' forecast errors. In addition, firms in countries having higher levels of individuality result in systematically higher levels of forecast accuracy. Based on suggestions by Hofstede (1983) it is possible the first relationship occurs because management does not willingly disclose firm strategies to outsiders. The second relationship may occur because management of firms in countries having high levels of individuality, such as the United States, disclose more extensive information to financial analysts (Zarzeski, 1996).

In regard to the dispersion of analysts' earnings forecasts, global managers should be aware that national culture dramatically influences how analysts predict earnings. Culture is the overwhelming predictor of the variability of analysts' forecasts. Because both culture and analysis of future earnings performance are complex, there are many potential reasons for disagreement about a firm's future earnings. For example, some cultures more readily disclose financial information and have a larger financial analyst community. In such cases, it has been reported that more financial analysts following a firm's activities will result in reduced cost of capital (Botosan, 1997). However, even though there may be larger analyst communities, the analysts face the daunting task of predicting earnings for firms with different strategies, different industry environments, and different company cultures.

For global financial managers interested in reducing the level of forecast error and dispersion for their firms, we offer the following actions plans:

1. In external communications to shareholders and the financial community, carefully disclose how the accounting standards of the home country maybe different than U.S. Generally Accepted Accounting Standards.

2. Discuss the cultural context of the home country in terms that relate to how the company makes critical decisions affecting the long-term approaches the business uses in developing competitive advantage.

3. Discuss the nature of the industry in which the firm competes with particular emphasis on driving forces of change in the industry.

4. Discuss the strategies employed by the firm at the present time and a forward-looking discussion of the likely business strategies to be implemented in the near-term.

\section{Implications for Financial Analysts/Global Investors}

The results of our study suggest that financial analysts who estimate earnings, and global investors who use earnings predictions, are impacted by "layers" of contingent factors affecting the accuracy and dispersion of earnings predictions in the global marketplace. For global investors using earnings predictions for capital market decisions, this study should increase the awareness that, in addition 
to industry environment, the business strategies and the national culture of a firm are important considerations. Since numerous studies have shown that the change in earnings from one period to another correlates positively with the change in stock price at earnings announcement, global investors should now include a greater understanding of these factors affecting the accuracy of earnings predictions.

\section{Implications for Academic Researchers}

There are a number of issues for future research. Our findings provide a useful departure for future inquiry into the interaction of culture, environment, strategy and performance predictions. We have shown that company financial reporting and investment community environments can be analyzed in more detail to determine more specifically the factors affecting earnings predictions. If more recent models of culture having additional cultural dimensions can be employed, further insight into the nation/structure/strategy/performance relationship will be gained. For example, future research should examine the information strategy, the product diversification strategy and the geographic diversification strategy of firms across different cultures. The global marketplace appears to be encouraging researchers from several disciplines to collaborate on studies that explain these global business relationships.

\section{References}

Abolafia, M. (1996). Making markets: Opportunism and restraint on Wall Street. Cambridge, MA: Harvard Press.

Adhikari, A. \& Tondkar, R. H. (1992). Environmental factors influencing accounting disclosure requirements of global stock exchanges. Joumal of International Financial Management and Accounting 4, 75-105.

Aldrich, H. (1979). Organizations and Environments, Englewood Cliffs, NJ: PrenticeHall.

Andrews, K. (1987). The Concept of Comotate Strategy, Homewood, IL: Irwin Publishing.

Bartlett, S. (1998). Who can you trust? BusinessWeek. October 5: 133-156.

Barrett, M. E. (1976). Financial reporting practices: Disclosure and comprehensiveness in an international setting, Journal of Accounting Research, 14(1), 10-26.

Barton, S. \& Gordon, P. (1988). Corporate strategy and capital structure. Strategic Management Joumal. 9, 623-632.

Botosan, C. (1997). Disclosure level and the cost of equity capital. The Accounting Review. 72(3), 323-349. 
Brown, L., Richardson, G. \& Schwager, S. (1987). An information interpretation of financial analyst superiority in forecasting earnings. Journal of Accounting Research. 25(1), 49-67.

Brown, L. \& Rozeff, M. (1978). The superiority of analyst forecasts as a measure of expectations: Evidence from earnings. The Journal of Finance. 33(1), 1-17.

Caves, R., Gale, B., \& Porter, M. (1974). Interfirm probability differences, Journal of Economic Literature. $88,181-192$.

Calderon, T. (1993). Predictive properties of analysts' forecasts of corporate earnings. Mid-Atlantic Journal of Business, 29(1), 41-58.

Cheng, A., Chan, K. \& Liao, W. (1997). An investigation of market response to earnings announcements: Multinational firms versus domestic firms. The International Journal of Accounting, 32(2), 125-138.

Cheng, C., Etheridge, H. \& Noland, T. (1994). Information complexity and the earnings response coefficient: A comparison of multinational and domestic firms. Advances in International Accounting. 7, 89-120.

Choi, F. (1973). Financial disclosure and entry to the European capital market. Journal of Accounting Research. 11, 159-175.

Conroy, R. \& Harris, R. (1987). Consensus forecasts of corporate earnings: Analysts' forecasts and time series methods. Management Science. 33(6), 725-39.

Das, S., Levine, C. \& Sivaramakrishnan, K. (1998). Earnings predictability and bias in analysts' earnings forecasts. The Accounting Review. 73(2), 277-294.

Das, S. \& Saudagaran, S. (1998). Accuracy, bias and dispersion in analysts' earnings forecasts: The case of cross-listed foreign firms. Journal of International Financial Management \& Accounting, 9(1), 16-33.

Dess, G. \& Beard, D. (1984). Dimensions of organizational task environments. Administrative Science Quarterly, 29, 52-73.

Dreman, D. \& Berry, M. (1995). Analyst forecasting errors and their implications for security analysis. Financial Analysts Journal, 51(3), 30-41.

Elton, E., Gruber, M. \& Gultekin, M. (1981). Expectations and share prices, Management Science. 27, 975-987.

Elton, E., Gruber, M. \& Gultekin, M. (1984). Professional expectations: Accuracy and diagnosis of errors, Journal of Financial and Quantitative Analysis. 19, 351-363. 
Erickson, H. \& Cunniff, J. (1995). A comparative look at consensus earnings in world markets. Journal of Investing, Spring, 19-28.

Fatemi, A. (1984). Shareholder benefits from corporate international diversification. The Journal of Finance, December, 1325-34.

Franke, R., Hofstede, G \& Bond, M. (1991). Cultural roots of economic performance: A research note. Strategic Management Journal, 12, 165-173.

Gonsalves, F. \& Eiler, G. (1996). Managing complexity through performance measurement. Management Accounting, August, 34-39.

Gray, S., J. Shaw, \& L. McSweeney. (1981). Accounting standards and multinational corporations. Journal of International Business Studies. 12, 121-136.

Hambrick. D. (1983). High profit strategies in mature capital goods industries: A contingency approach. Academy of Management Journal. 26, 687-707.

Hambrick, D. \& Lei, D. (1985). Toward an empirical prioritization of contingency variables for business strategy. Academy of Management Journal. 28, 763-788.

Hitt, M. \& Ireland, R. (1987). Building competitive strength in international markets. Long Range Planning, 20(1), 115-122.

Hofer, C. (1975). Toward a contingency theory of business strategy. Academy of Management Journal, 18, 784-810.

Hofstede, G. (1983). The cultural relativity of organizational practices and theories. Journal of International Business Studies, Fall, 75-89.

Hofstede, G. (1980). Culture's consequences: International differences in work-related values. Beverly Hills, CA: Sage Publications.

Hunter, J. \& Coggin, T. (1998). Analyst judgement: The efficient market hypothesis versus a psychological theory of human judgement. Organizational Behavior and Human Decision Processes. 42, 284-302.

Jauch, L., Osborn, R. \& Glueck, W. (1980). Short term financial success in large business organizations: The environment-strategy connection. Strategic Management Journal, 1, 49- 63.

Katz, J., Werner, S. \& Brouthers, L. (1999). Country goal orientation differences of global competitors: An empirical assessment of U.S., Japanese, and EC banks. Journal of Business Research. 44(2), 117-126. 
Katz, J., Zarzeski, M. \& Hall, J. (1997). The importance of strategy to global competitors: The strategy-performance relationship across cultures. Journal of Business Strategies. 14(2), 126- 140.

Lang, M. \& Lundholm, R. (1996). Corporate disclosure policy and analyst behavior. The Accounting Review, 71(4), 467-92.

Leblebici, H. \& Salancik, G. (1982). Stability in interorganizational exchanges: rulemaking processes of the Chicago Board of Trade. Administrative Science Quarterly, 27, 227242.

Lee, M., Lee, I., \& Ulgado, F. (1993). Marketing strategies for mature products in a rapidly developing country: A contingency approach. Intemational Marketing Review. 10(5), 56-72.

Mann, J. 1998. Earnings forecast bruises stock: Interstate Bakeries says it doubts it will meet analysts' predictions. The Kansas City Star, October 31: B 1.

McArthur, A. \& Nystrom, P. (1991). Environmental dynamism, complexity and munificence as moderators of strategy-performance relationships. Journal of Business Research. 23, 349- 361 .

Mitroff, I. \& Mohrman, S. (1987). The slack is gone: How the United States lost its competitive edge in the world economy. Academy of Management Executive 1(1), $65-70$.

Nakata, C. \& Sivakumar, K. (1996). National culture and new product development: An integrative review. Journal of Marketing, 60, 61-72.

Olsen, R. (1998). Behavioral finance and its implications for stock-price volatility. Financial Analysts Journal. 54(2), 10-18.

Osland, G, \& Cavusgil, S. (1996). Performance issues in U.S.-China joint ventures. California Management Review. 38(2), 106-130.

Patell, J. (1976). Corporate forecasts of earnings per share and stock price behavior: Empirical tests. Journal of Accounting Research, Autumn, 246-76.

Peterson, M. et al. (1995). Role conflict, ambiguity, and overload: A 21 nation study. Academy of Management Journal. 38(2), 429-452.

Porter, M. (1990). The competitive advantage of nations. New York: Free Press.

Porter, M. (1985). Competitive advantage. New York: Free Press

Porter, M. (1980). Competitive strategy. New York: Free Press. 
Prescott, J. (1986). Environments as moderators of the relationship between strategy and performance. Academy of Management Joumal. 29, 329-346.

Rasheed, A. \& Prescott, J. (1992). Toward an objective classification scheme for organizational task environments. British Joumal of Management. 3(4), 197-206.

Rivera, J. (1991). Prediction performance of earnings forecasts: The case of U.S. multinationals. Journal of International Business Studies, Second quarter, 265-288.

Rockart, J. (1979). Chief executives define their own data needs. Harvard Business Review. 57, 81- 98.

Scherer, F. (1970). Industrial market structure and economic performance. Chicago: Rand McNally College Publishing.

Shaked. I. (1986). Are multinational corporations safer? Journal of International Business Studies, Spring, 83-106.

Shane, S. (1993). Cultural influences on national rates of innovation. Journal of Business Venturing, 8(1), 59-73.

Shefrin, H. \& Statman, M. (1993). Behavioral aspects of the design and marketing of financial products. Einancial Management. 22(2), 123-134.

Shipper, C. (1991). Commentary on analysts' forecasts. Accounting Horizons, December, $105-121$.

Solnik, B. (1974). The international pricing of risk: An empirical investigation of the world capital market structure. The Journal of Finance, May, 48-54.

Speidell, L. \& Ramos, E. (1998). Do earnings estimates matter? Joumal of Investing, 7(2), 23-31.

Venkatraman, N. \& Ramanujam, V. (1986). Measurement of business performance in strategy research: A comparison of approaches. Academy of Management Review. 11(4), 801-814.

Vlasic, B., Kerwin, K., Woodruff, D., Peterson, T., \& Spiro, L. (1998). The first global car colossus. BusinessWeek, May 18, 40-43.

Zarzeski, M. (1996). Spontaneous harmonization effects of culture and market forces on accounting disclosure practices. Accounting Horizons. 10(1), 18-37. 
Jeffrey P. Katz is an Associate Professor in the Department of Management and The Payless ShoeSource Professor of Business at Kansas State University where he conducts research and teaches strategic management and international management. He received his doctor of philosophy in strategic management from the University of Florida's Graduate School of Business Administration. His research examines the role that national programs play in the international competitiveness of global firms. His work has appeared in the Academy of Management Journal, Academy of Management Executive, Business Horizons, Human Resource Planning Journal, International Journal of Management, Journal of Business Strategies, Long Range Planning, and the Journal of Business Research. He is a former Fulbright Senior Scholar at the University of Giessen, Germany.

Marilyn T. Zarzeski is Croft Associate Professor of Accounting at The University of Mississippi and has earned three research awards. Prior academic assignments include the University of Central Florida and Barry University. She earned her Ph.D. at the University of Florida in 1994. She received her CPA license in 1978, after earning her MBA at Youngstown State University. Prior to academe, Marilyn did auditing and accounting for American Express, CIGNA, Flagship Bank, and Keller Industries.

H. John Hall is the Director of the Master of Arts in International Business program in the Warrington College of Business Administration at the University of Florida. $\mathrm{He}$ received his $\mathrm{Ph}$.D. at the University of Georgia. His research interests include strategic decision making and entrepreneurship. He is a Heiser Award recipient for outstanding research in entrepreneurship by the Academy of Management. He has presented executive workshops in the U.S. and numerous other countries.

The authors gratefully acknowledge $\mathrm{I} / \mathrm{B} / \mathrm{E} / \mathrm{S}$ International, Inc. for providing financial forecast data through the Institutional Brokers' Estimate System and the helpful comments provided by the $J B S^{\prime}$ reviewers and editors. 